\title{
THE PEDAGOGY OF SHAME. EDUCATION IN THE FACE OF THE DEMOKRATUR ${ }^{1}$ OF IGNORAMUSES
}

\author{
ALEKSANDER KOBYLAREK \\ Institute of Pedagogy, University of Wrocław \\ J. Wł. Dawida 1, 50-527 Wrocław, Poland \\ E-mail adress: aleksander.kobylarek@gmail.com \\ ORCID: https://orcid.org/0000-0002-4562-9035
}

\begin{abstract}
This article relates to the slogan of one of the populist political parties in Poland "the pedagogy of shame". It is an example of manipulation and the creation of simulacra in social life in order to justify the necessity of assuming power. On accomplishing this, the slogan becomes the primary principle in the management and rearing of a new society fed on illusions. The author points to the deeper roots of pathologies which define corrupted power - indifference to or acceptance of minor injustices, lack of civic engagement, insouciance with regard to the natural and social environments, the creation of unhealthy arrangements and relationships in small social groups and institutions, including educational - from the lowest level up to the university. In conclusion, the author indicates the necessity of supporting the development of civic society as understood by M. Gruntvig.

Key words: feudalism, civic education, threat to humanity, scientific education, political simulacrum
\end{abstract}

\section{THE ROOTS OF THE PATHOLOGY}

For several years we have seen a very interesting phenomenon in the social life of many countries, which is difficult for contemporary science to explain. In many developed societies democratic mechanisms have brought forth antidemocratically disposed political forces. Local commentators on the political arena point to a new political system which has the appearance of democracy (parliamentary system, democratic elections, free media) but in

1 Ger. = portmanteau of "democracy" and "dictatorship", used to describe authoritarian tendencies in democracy (equivalent of Polish "demokratura") 
which, at the same time, the gradual appropriation of independent institutions, their manipulation and deprivation of rights, is taking place. In effect, a hybrid political system comes into being which can be described as "demokratur" partly democratic and partly authoritarian, using the method of fait accompli, symbolic force and a specific interpretation of the law that serves obtaining material advantages strengthening their grip on power and gaining yet more benefits. In some countries, with a stronger and more established democracy, this process happens relatively gently and is limited to the politics of fake news and the maximum use of power obtained with the help of lies and populist half-truths. In other countries, the democratic institutions appear to be helpless and fall prey to the representatives of the new power, which at all costs strives to gain influence over the whole of the social life, including justice.

Such a situation was known earlier. Authoritarian regimes, afraid of sanctions by the international community, attempt to maintain the appearance of democracy by constructing the so-called "façade democracy". This allows them to somehow function in international relations and to expect at least some degree of tolerance from more liberal democracies. Unsurprisingly, such political strategies can be found in poor underdeveloped post-colonial countries with a weak political culture, or in banana republics, but it is a total shock for western civilization when elements of demokratur appear in countries belonging to that cultural sphere and accepting its basic principles (such as law, justice and freedom) as being of the highest value.

There are many attempts at explaining the abandonment of ideals by the leaders of liberal democracies. We can see the reason for this state of affairs in: - media simulacra (Baudillard, 1988) and fake reality (the media manipulates public opinion; by drawing the public's attention to extremists, the media increases the power of populists and political frauds, which in turn increases their popularity) (Keyes, 2004);

- difficult history of some democratic countries (for example, young democracies may be less stable) (Jacobsson \& Korolczuk, 2017);

- the particular personalities of voters or leaders (voters portrayed as supporters of conspiracy theories or as homo sovieticus (Zinowjew, 1983), whereas leaders are perceived to have Machiavellian or psychopathic personalities) (Marmion, 2018);

- general and widespread aversion to the political elite, domination of negative elections (against parties and their leaders) as opposed to positive elections; the lower the number of people taking part, the greater the probability of elections which are random, negative and ill-conceived, influenced by emotions fuelled by extreme political forces.

The effect of elections based on emotions is a deepening social and political chaos, incomprehensible to people who are educated, wise and convinced of a need to strive for social justice. For the less knowledgeable, it is a simple battle for power whose rules they do not need to understand, while for others it is a pathetic display of vanity fireworks, mixed with dilettantism and contempt for the people put forward by the representatives of the new power's pseudo-elite. 
The amount of ignorance displayed by these new power elites is amazing (Allocca, 2018). One can be convinced about this many times many times, even during the outbreak of a pandemic when many leaders did not react appropriately. In effect it is the communities and not the leaders who have to pay the heavy price for the ignorance of the authorities. Observing the manipulative actions of demokratur, one may get the impression that some of their representatives never even went to school, because they do not know how to count or read with understanding, and they appear to possess very limited key competences for functioning in the contemporary world. Decision-making and its justification are illogical, feverish and often at variance with common sense. Thus we do not know whether these decisions are the result of ignorance, stupidity, nonchalance and contempt, or some cynical settling of accounts with perceived elites. We are more inclined to suppose that it is the result of a poor, superficial education, just as in the case of their electors.

\section{HIDDEN DEMOKRATUR}

Demokratur in the political arena did not appear out of the blue. Not without reason it is said that political elites to a certain extent mirror their electors. Elites created by ignoramuses are legitimised by ignoramuses, same as them or similar. People who are against vaccination choose those who are not disgusted by the idea of the danger of injections, and flat-earthers support those who had a problem understanding basic material from primary school (Egan, 1998). Browbeating people, expressing contempt, committing larceny and lawbreaking do not bother those for whom they appear acceptable. This also applies to those who are indifferent, because by being indifferent and passive, they agree to corruption and illegitimacy. We can also further conclude that what we observe in political life at the highest level of power may also be happening at lower levels. Everywhere where we are dealing with management, there is also the danger of authoritarianism (Laloux, 2015). There is much to indicate that authoritarian inclinations in management existed earlier, during the period of ideological liberal democracy, and are unexpectedly emerging now at the beginning of the $21^{\text {st }}$ century. They certainly existed in those institutions where the possibility of arbitrational solutions, co-operation between partners, reconciliation and communication on equal standing is either limited or informal. In both cases we are dealing with total institutions with strong determined power, which are easily able to impose obedience.

Authoritarianism, compulsion, psychological pressure, and conformism are phenomena rather difficult to research, particularly in the scientific environment. The victims of such a system have no chance. Unreliable reviewers, dishonest sponsors and other kinds of aggressor can feel themselves exempt from punishment, especially in the humboldtian model of university (Kobylarek, 2017), where more titles means a bigger share of power and decision-making, and the professor has the last say in every matter, even those of which he or she 
has absolutely no knowledge. And certainly not every professor has knowledge of teaching and management, whilst in the scientific environment this is treated as nothing but an axiom. This same axiom, in an extended form, assumes that nobody from a lower level can undermine the opinion of a superior or somebody who has more titles, no matter how much he or she has published, how big his or her scientific output is, or his or her experience. The person standing higher in the hierarchy of title and position must know more and can therefore decide the fate of those below him or her. This can explain the resistance of the scientific community in cases of uncovered and publicized pathologies such as plagiarism, incompetent reviews, blocking the careers of unfavoured colleagues, and the forming of cliques and conspiracies in order to maintain power or promote nonentities connected by marriage (Świtalska, 2010). The aggressor's colleagues have no interest in reaching the truth, and the rest would not dare doubt the infallibility of the professor's authority.

However, there is no doubt that an educated teacher generally knows more than a self-educated professor who, while teaching his or her students, never came across modern didactic concepts. Similarly, the dean and rector know less about management then the average MBA graduate. Contrary statements seem an absurd, but in practice this is precisely the management of the modern humboldtian university (Błaszczyński, 2013). The assumption of the necessary independence of the professor has led us to the absurd situation of slavery in the face of scientific titles. The independence of the professor has led to the dependence of all others, who are by definition considered stupid and undereducated.

The situation in the scientific community has been cited as an example of the functioning of the demokratur of ignoramuses in an environment where the uninitiated would never suspect it being. On the one hand, this may appear surprising, but on the other, in many environments it is invisible from the outside. If, however, such a situation can be found in such an intelligent environment as science, what could be going on in less enlightened communities for which, after all, the university is a role model and point of reference?

This leads us straight to the conclusion that social behaviours modelled on demokratur may be firmly anchored in the whole education system. This, through a hidden curriculum, convinces us that power and resources can only be obtained by becoming fixed in defined social arrangements, above all by carrying the boss's briefcase, or performing drudgery for our superiors in the role of a peasant running errands or a complaisant sycophant.

\section{THE PEDAGOGY OF SHAME}

In this whole mess, pedagogy as a scientific discipline is in a rather specific situation (Kobylarek, 2019). It is fairly often the object of contempt by exponents of science who feel that they are representatives of the one true knowledge, at the same time, refusing to give pedagogy the status of a sci- 
ence. The representatives of pedagogy do not help in dispersing this illusion. Too often they are focused on ideological battles instead of research, unnecessarily complicating and damaging the language, and retreating to topics which have little to do with pedagogy, without reference to their mother discipline, as if they were a little ashamed of following a rather unimportant scientific discipline. In many European countries pedagogy is associated only with education practice.

In the context of the demokratur problem, what appears to be most important are accusations of ideological involvement. This applies not only to pedagogy but also generally to promotion in the humanities and social sciences. Alliances, anticipated coalitions, and counting votes in factions of enemies and allies must always take ideological involvement into consideration, right at the level of candidates for promotion at particular stages of assessment. A leftwing candidate has no chance before a right-wing orientated committee, just as a right-wing applicant in conflict with a left-wing reviewer. The question arises as to whether in these conditions it is possible to rise above personal values and impartial assessment.

The expression "the pedagogy of shame" came into being because in Poland it has made a staggering political career during the last five years. The ruling populist party used this expression during the battle for the electorate, suggesting that previous regimes had taught their citizens only shame in relation to the West. According to them, since Poland entered the European Union the political elite has displayed servility and deference. This was obviously manipulation, appealing to the primitive false pride of the poorly educated and marginalized. After coming to power the same party, through its numerous actions, perversely showed that the real shame was only about to begin. All intelligent people were to be ashamed by the fireworks of administrative stupidity they were presented with. Thus, the term "the pedagogy of shame" became a kind of symbol of the demokratur of ignoramuses - the insolent behaviour of people acting in bad faith and making nonsensical decisions from the point of view of the common good. For intelligent people, these absurd decisions are all the more shocking in that they are frequently supported by the professors whom until then they had trusted en masse (Kobylarek, 2016, see also Benda, 1928).

Thus it turned out that neither scientific title nor education are a guarantee of immunity from stupidity. This in turn leads us to further doubts as to the value of science, work and education, upon which until now we have built our society. Suddenly it turns out that one can be an undereducated bandit, yet still receive support from a manipulated mob. One can charm and abuse all educated people beyond one's possibilities, turning them first into neophytes and then acolytes of the new system, leading them into the role of obsequious sycophants.

This is the consequence which is most destructive for education. As teachers and academics, what can we say to the young people under our care? It is possible to form the impression that the demokratur of ignoramuses is a clear 
contradiction of the systematic ideals of education. Why learn when an uneducated simpleton can become president of your country? Why work hard when the relatives and friends of a cockroach can make careers for themselves? Why respect the law if the representatives of power (and even their lawyers) do not respect it? Maybe it is knowing the right people and being in the right informal networks that constitute a passport to a career and power?

Obviously these are rhetorical questions, because society cannot function and develop without specialists. Pathologies in management, whether it is at the level of an educational institution or business, or on the scale of the whole nation, cannot become examples on the basis of which we are supposed to plan our lives and professional careers. However, the demokratur of ignoramuses must arouse justifiable existential disquiet, and the position of all those working with knowledge (including teachers) becomes particularly difficult. We should therefore suppose that the demokratur of ignoramuses, understood as a government of idiots acting behind a façade of democracy, must fairly quickly succumb to erosion and self-destruction. However, the losses for public life will be difficult to calculate. We should expect an increase of mistrust towards decent people, all the teachers and workers with knowledge who took care to create honest science. We can suppose that after such an epistemological and ethical catastrophe that we are currently experiencing, it will be difficult to return to a satisfactory level of faith in science and fundamental values such as the law, honesty, integrity and impartiality. For some time educators may be perceived as manipulators (after all, even professors and lawyers have gone to the dogs) or suckers, who let a bunch of cunning twisters take advantage of them. Perhaps for several generations a clinging odium will overcome those societies who succumbed to anti-science and populist hysteria, as in the case of German society after World War II. Briefly, it will be difficult for us to shake off the lack of social trust, and the reconstruction of social capital may take decades.

\section{WAYS OUT}

Although today we cannot see the end of this long and exhausting process of destruction of our fundamental values, there is no doubt that this state of affairs will not last forever, and we should be preparing for the fall of a counterfeit world defined as the truth by the strong who to this end use institutional and symbolic aggression. We should already be thinking of how to put ourselves together again in the face of the scientific and moral devastation left by governments practising the demokratur of ignoramuses.

Above all, the causes of this phenomenon should be considered. And the causes lie in our everyday demokraturs and acquiescence to minor authoritarianisms in businesses and educational institutions. If "little Hitlers" were not tolerated in micro-worlds, nobody would dream of showing themselves publicly in the role of a "greater Hitler". Thus, work needs to be done with 
the mentality of the people so that they have more civic courage and use the mechanisms available to them in order to eliminate local pathologies.

The next element in this social jigsaw puzzle is law and power, which ought to exercise justice accurately. Victims of the system feel defenceless and the oppressors immune from punishment when the law is not worth the paper it is written on. A change in mentality will not be possible without a simultaneous change in the law and the tough consequences of its execution. Only the inevitability of punishment can deter law-breaking (Turkle, 2017).

A change in mentality can only be achieved thanks to general multi-dimensional and reliable education, based on scientific achievement, laundered of religion and avoiding worldview entanglement, but also focused on what is most important - verified basic knowledge, and the key competences and skills necessary to function in everyday life. Incidentally, it is worth noting that the more information the school curriculum contains the more we confuse what is relevant with what is supplementary, incidental and explanatory. Current school curricula are overloaded, and burden the pupils with unnecessary details which they do not need to know in order to understand the essence of the most important processes and phenomena.

Education for building communities, solidarity and social capital should be one of our priorities. Thus it is necessary to overcome divisions, eliminate contempt, and rebuild trust, so that nobody will ever be taken in by "the pedagogy of shame". Good education should lead to the emergence of an appropriate power which can be held to account at any moment in its tenure. This will not be possible without the initiative of citizens who will feel responsible for their social and natural environments. This also means that civic awareness should become the most important educational priority. With this in mind it is worth reaching for the well-formulated proposal of M. Grundvig.

These recipes appear to be simple, but for several reasons, they will be difficult to accomplish. First and foremost, it will be difficult to rebuild communities after ideological wars and the destruction of trust through various kinds of swindling Pied Pipers of Hamlin. First, their power and possibility to influence should undergo verification. Next, a return to the scientific roots of knowledge should bring with it the necessity of settling accounts with various kinds of charlatans. It is not acceptable that a professor, doctor, politician, chaplain representatives of professions requiring public trust - are involved in scandals, morally questionable activities, the propagation of hate, the shattering of communities, or even common criminality. Discreditable actions should lead to loss of the right to practice a profession, because black sheep affect the opinion of the flock and shatter trust. Growing anger and despondency among the people will only deter them from taking part in community life and then we are back to square one (Kobylarek, 2015).

What would happen, however, if the world did not return to rationalism, law, solidarity and honesty and the demokratur of ignoramuses lasted for a long time, measured in generations or even centuries? Then the digression described above has no sense, just like philosophy, science and educa- 
tion (Braidotti, 2013). Only strength and aggression would count. The weak would have no guaranteed rights and the value of a person would be defined by his or her usefulness. Sooner or later a kind of subsidence into oblivion awaits us.

\section{REFERENCES}

[1] Allocca, K. (2018). Videocracy: How YouTube Is Changing the World . . with Double Rainbows, Singing Foxes, and Other Trends We Can't Stop Watching. London-New York: Bloomsbury Publishing.

[2] Baudrillard, J. (1988). Selected Writings. Stanford: Stanford UniversityPress.

[3] Benda, J. (1928). The Treason of the Intellectuals. New Brunswick and London: Transaction Publishers.

[4] Błaszczyński, K. (2013). Zmierzch bogów - o zasadności likwidacji habilitacji i profesury w Polsce i krajach europejskich [The twilight of the Gods - on the validity of the abolition of habilitation and professorships in Poland and European countries]. Ogrody Nauk i Sztuk(3), pp. 54-63.

[5] Braidotti, R. (2013). The Posthuman. Cambridge: Polity Press.

[6] Egan, K. (1998). The Educated Mind: How Cognitive Tools Shape Our Understanding. Chicago: University of Chicago Press.

[7] Jacobsson, K., \& Korolczuk, E. (2017). Civil Society Revisied. Lessons from Poland. New YorkOxford: Berghahn Books.

[8] Keyes, R. (2004). The Post-Truth Era: Dishonesty and Deception in Contemporary Life. New York: St. Martin's Press.

[9] Kobylarek, A. (2015). The Internet as a new chance for academic communities. Journal of Education Culture and Society (1), pp. 5-8.

[10] Kobylarek, A. (2016). Seven cardinal sins of science. Journal of Education Culture and Society (2), pp. 5-8.

[11] Kobylarek, A. (2017). Polish Humboldtian University in the Face of Paradigmatic Change. Cambridge Scholars Publishing.

[12] Kobylarek, A. (2019). Education in the post-scientific culture. Journal of Education Culture and Society(1), strony 5-13.

[13] Laloux, F. (2015). Reinventing Organizations: Ein Leitfaden zur Gestaltung sinnstiftender Formen der Zusammenarbeit. München: Vahlen Franz GmbH.

[14] Marmion, J.-F. (2018). Psychologie de la connerie. Lyon: Sciences Humaines Eds.

[15] Świtalska, A. (2010). On the abuses by the thesis supervisor in the light of the academic ethos. Journal of Education Culture and Society, 5-18.

[16] Turkle, S. (2017). Alone Together: Why We Expect More from Technology and Less from Each Other. New York: Basic Books.

[17] Zinowjew, A. (1983). Homo sovieticus. Warszawa: EPUB. Polonia. 